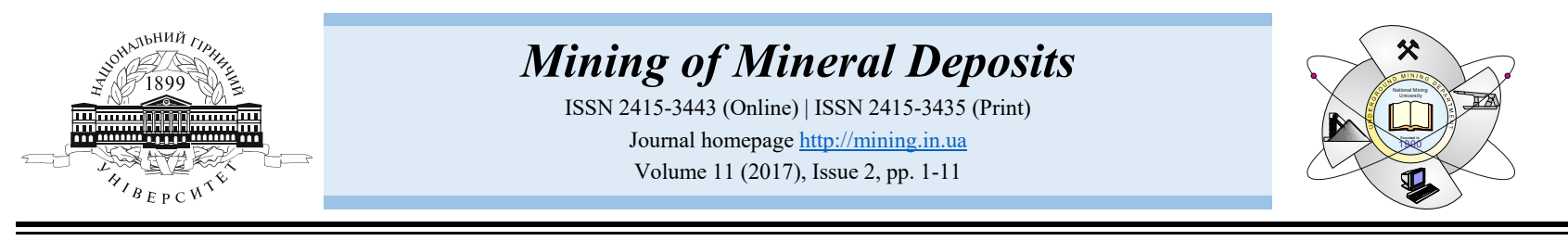

UDC 622.3:658.5

https://doi.org/10.15407/mining11.02.001

\title{
TECHNOLOGICAL SAFETY OF SUSTAINABLE DEVELOPMENT OF COAL ENTERPRISES
}

\author{
V. Bondarenko ${ }^{1}$, V. Cherniak ${ }^{2 *}$, F. Cawood ${ }^{3}$, V. Chervatiuk ${ }^{4}$ \\ ${ }^{1}$ Underground Mining Department, National Mining University, Dnipro, Ukraine \\ ${ }^{2}$ Production Sphere Management Department, National Mining University, Dnipro, Ukraine \\ ${ }^{3}$ Wits Mining Research Institute, University of the Witwatersrand, Johannesburg, Republic of South Africa \\ ${ }^{4}$ LLC "DTEK Energy”, Kyiv, Ukraine \\ *Corresponding author: e-mail vi chernyak@ukr.net, tel. +380993425484
}

\section{ТЕХНОЛОГІЧНА БЕЗПЕКА СТІЙКОГО РОЗВИТКУ ВУГІЛЬНИХ ПІДПРИЕМСТВ}

\author{
В. Бондаренко ${ }^{1}$, В. Черняк ${ }^{2 *}$, Ф. Кейвуд ${ }^{3}$, В. Черватюк ${ }^{4}$ \\ ${ }^{1}$ Кафедра підземної розробки родовищ, Начіональний гірничий університет, Дніпро, Украӥна \\ ${ }^{2}$ Кафедра менеджменту виробничої сфери, Національний гірничий університет, Дніпро, Україна \\ ${ }^{3}$ Гірничий дослідний інститут, Вітватерсрандський університет, Йоганнесбург, Південно-Африканська Республіка \\ ${ }^{4}$ ТОВ “ДТЕК Енерго”, Киї, Украӥна \\ *Відповідальний автор: e-mail vi_chernyak@ukr.net, тел. +380993425484
}

\begin{abstract}
Purpose. Substantiation of conceptual base of searching the ways of threats prevention to sustainable development of coal enterprises in the presence of multidirectional vectors of economic pressure of the external environment.

Methods. Methods of the structural and comparative analysis for an assessment of usage of the main definitions of a research, their essence and communication with other categories which define efficiency of development of the coal enterprise are used for the solution of the set tasks in the work; groups and classifications are used for systematization of types of economic security and stability of the enterprise, and also factors which cause them.

Findings. The analysis of main definitions that reflecting essence of such scientific phenomena as "sustainable development" and "economic security" of the enterprise is conducted. Actuality and reasonability of scientific research conducting on formation of methodical base and tools of an assessment of a technological component of sustainable development safety of coal enterprises is substantiated.
\end{abstract}

Originality. Research of opportunities of the comprehensive programs creation of adaptive management of the mining enterprise including a retrospective and perspective assessment of a pathway of its development.

Practical implications. Introduction of adaptation activity at the coal enterprises in aspect of process of technological safety ensuring.

Keywords: coal enterprise, technological safety, economic stability, stable functioning

\section{INTRODUCTION}

Nowadays, the world coal industry is nearly the most difficult sphere of economic activity from the point of view of an assessment and realization of prospects of its further development.

Such situation, on the one hand, is caused by the increasing role, weight and economic feasibility of alternative energy sources implementation. Already more than 30 countries of the world have proclaimed that they have reached smaller costs of their usage in relation to traditional sources on the basis of coal, oil and gas and even nuclear power. It leads to the fact that the governments are skeptical about necessity of the state support of the coalmining enterprises and providing any preferences to them.

On the other hand, the industry continues to provide millions and millions of work places not only at the enterprises, but also in partner spheres, such as metallurgy, mechanical engineering, chemical industry, etc. Besides, increased investments into technological development of the enterprises connected with complication of mining-andgeological conditions of coal mining from year to year.

Presence of such multidirectional vectors of economic pressure leads to necessity of acceptance by the enterprises of measures for prevention of threats for steady functioning. 
In domestic practice it is necessary to add to these factors also political one, which consequence of action violation of integrity of the organizational and economic mechanism of management of industry and coordination of work of the state and private sectors of coal mining has turned out. In such conditions, so far, only the Donbass Fuel and Energy Company (DTEK) keeps perspective technical and technological base for improvement organizational and economic making productions of coal output. For the last 11 years, Company invested nearly UAH 20 billion in development of mines (Derun, 2016).

Since 2013, on DTEK enterprises the system of economical production "Innovator" based on rules of the Toyota production system (Toyota Production System TPS) which principles and tools have found reflection in its American option - system of economical production of LEN (LEN - Lean Production). Its represented as a certain complex of actions for management of the organization which are directed on improvement of quality of work due to reduction of losses. And even in a year of implementation, the effect of introduction of "Innovator" at the DTEK coal enterprises has made only UAH 8.2 million, then in the next years it has considerably increased, and in 2014 has reached to UAH 66.6 million, and in 2015 has exceeded the amount of UAH 270 million. For today, statistically, each 20 minutes in DTEK the new idea on ensuring lean manufacturing is suggested.

However, the system strategy of maintenance of competitiveness and development of the coal-mining enterprises can be constructed only on a strong scientific and methodical basis (Kharlamova, Nate, \& Chernyak, 2016). Such scientific approaches to increase in efficiency of activity of the enterprises urgent today as "concept of sustainable development of the enterprise" and "concept of economic security of the enterprise" can make its conceptual basis of construction (Vorotnikov, 2014). At the same time, it is necessary to consider that mining industry has certain specifics of activity which are available dynamic working space that imposes certain restrictions for usage of classical scientific approaches to ensuring sustainable development of the enterprises.

The attention was already focused on the fact that enterprises of coal industry have specific conditions which can influence on functioning of safety mechanism of sustainable development. Works that devoted to enterprises of mining and metallurgical complex (Slobodchikova, 2016; Amoosha, Starichenko, \& Cherevatskyi, 2013; Dhookie, 2016) are testified about that.

The attention of the last research on this issue concentrates generally on economic and financial aspects of stability of the coal enterprises, and "technology", though is noted as a significant factor, but remains beyond the scope of research. Furthermore, for instance, in work of Trifonova (2015), concentrating on a perspective of "stability of the enterprise" and "stability of functioning of the enterprise" (including coal mines), researchers let go that as it has been shown above, these phenomena can be considered only as the separate moments of "sustainable development of the coal enterprise" and can't be considered as the complete business strategy of the enterprises of coal industry.
Weighing features of functioning and development of the coal enterprises and considering the level of scientific developments on the designated perspective, it is possible to note that the special attention is required by a technological component of safety of sustainable development today.

\section{PRINCIPLES OF ADAPTATION PROGRAMS FORMULATION OF COAL MINES DEVELOPMENT}

Any operating mining enterprise and coal mine in particular, represent the difficult dynamic system that functioning in continuously changing conditions of the internal and external environment.

For instance, volumes of daily updates of working space on stoping and preparatory mine workings on coal mines of DTEK in 2016 exceeded $60000 \mathrm{~m}^{3}$ (Fig. 1), i.e., every day cardinal transformations of space of 5 football fields on height in human growth were undergo.

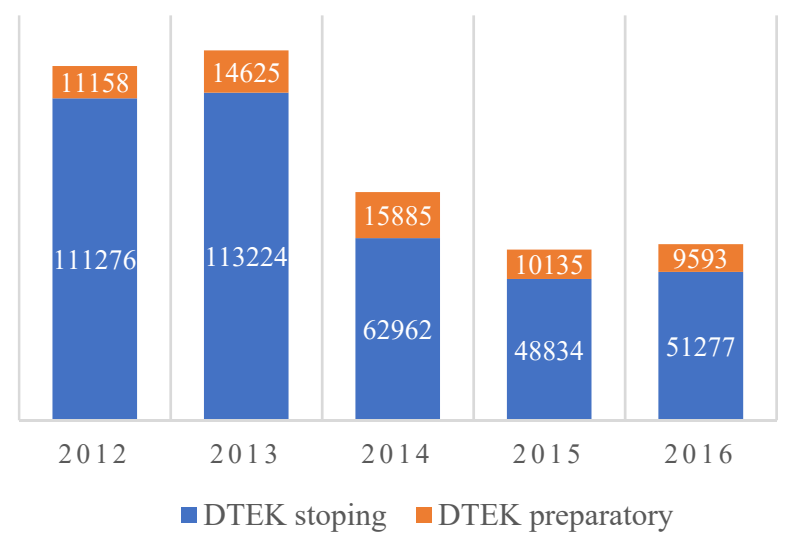

Figure 1. Changes of working space on DTEK coal mines

Advance of the front of stoping and preparatory operations, displacement of roof and bottom rocks, changes of gas-and water abundance of mine workings - all these lead to necessity of ensuring stability of functioning and development of the enterprise and, respectively, development and implementation of projects (programs) that allowing to create such maintenance. Furthermore, it is necessary to consider instability factors that connected with the level of readiness of stocks for application of these or those technological schemes. According to Khetagurov (2013), mineral reserves which are initial product of the nature, have significant effect on overall performance of the rock enterprise for this reason:

- have no starting cash value in its classical sense;

- placement and total number of resources (category A, B, C1 and C2) in subsoil have various degree of a probabilistic assessment;

- in each time point, the assessment of deposits stocks is confirmed by data of the reconnoitered part of stocks, and the information about them is replenished with expansion of its industrial development;

- resources of minerals are non-reproducible, and at the same time can be filled up due to geological investigation; 
- the constant preparation of the new front is necessary for providing a continuity of production drivage of permanent and preparatory mine workings, operations on supporting of mine workings, construction and equipment of transport communications and so forth;

- initial expenses on preparation of the new front conducting is very essential and demands a considerable advancing in time of mining operations;

- fields and their sections are characterized by very various conditions of a bedding and quality of minerals and, as a result, efficiency potential;

- the infrastructure of the enterprise including a complex of buildings and constructions in the absence of effective reserves of mineral, and practically, has no market value.

Basing on analysis of industry specifics of activity, it is possible to predict with confidence that for coal mines in such ways of development today is increasing in adaptive abilities of the enterprise to mining-and-geological conditions of development of deposits and research of technical-and-technological capabilities of ensuring expanded reproduction.

The comprehensive programs of adaptive management including a retrospective and perspective assessment of a trajectory of development of mining enterprise, identification of critical stages, dangers, risks, emergency situations which can change the developed tendencies, form a basis of such work and create the innovative potential of ensuring safety and steady functioning.

Set of interrelations of properties and opportunities of the developing objects, their parametrical reflection also makes a structural and logical basis (Fig. 2) of adaptation programs for the mining enterprises reproduction.

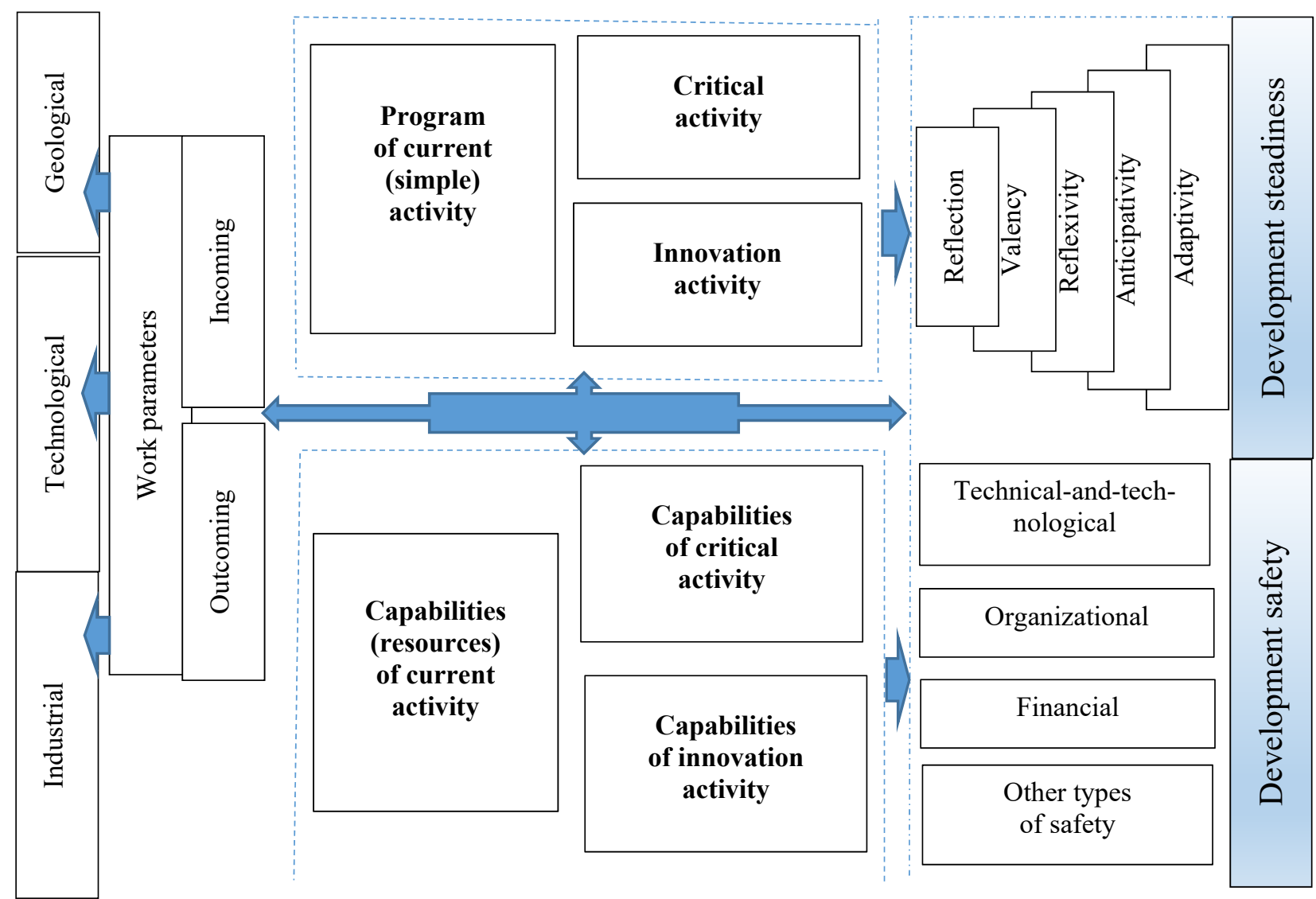

Figure 2. Structurally-and-logical scheme of programs elements interaction of adaptive management on coal mines

Problems of adaptability, adaptation process, adaptive management of the enterprises are subject to close attention of scientists. At different times in the context of development of the enterprises, such authoritative foreign scientists as D. Andresen, I. Ansoff, J. Dixon, P. Segne, A. Setkhi, and S. Setkhi, V. Stephenson who have laid the theoretical and methodological foundation of the concept of adaptive management of the enterprises were engaged in such tasks.

Usage of the basic principles of programs of adaptive management of technological processes on DTEK mines within such actions have allowed to reduce necessary volumes of updates of working space almost twice
(Fig. 3), reducing thereby potential area of critical activity and increasing technological safety of production. And if in 2012-2013 practically the same volume of mined rocks fell on each cubic meter of the extracted coal, now it was reduced almost by 3 times (Salli, Mamaykin, \& Smolanov, 2013).

The cumulative effect from realization of innovative actions on Ukrainian coal mines of DTEK during the period from 2013 to 2016 has made about UAH 480 million that at the cost of "start" of one longwall of UAH 50 million, it corresponds to economy of commissioning of 10 stoping faces. 


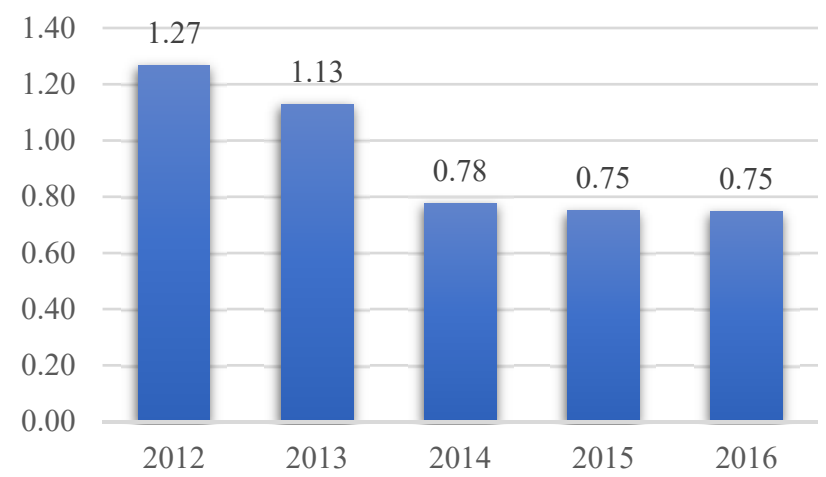

Figure 3. Efficiency of implementation of adaptation programs of stoping and preparatory operations technology in conditions of DTEK mines (daily renewals of working space on 1 ton of extracted coal, cubic meters)

At the same time, it is necessary to consider what consequences of the entered innovations can exert negative impact on balance of safety and stability. Such influence not always happens obvious, especially if the indicators that characterizing adaptability weren't considered in advance and borders weren't projected in calculations, and borders or scale of values of its level are also not developed.

For prevention of negative consequences of such plan, on the basis of the analysis of theoretical and methodical base of a research of adaptation processes and the phenomena in functioning of the enterprises, the following complex of requirements (A) and principles is proposed (B), on the basis of which adaptation programs of development of coal mines have to be formed (Chernyak, 2004):

A. Adaptation programs of coal mines development has to meet the following requirements:

- to have the high flexibility allowing to change quickly;

- to have high mobility in adoption of administrative decisions and their realization in life;

- to be an adequate to current situation;

- to consider the serious competition;

- to consider requirements for professionalism level;

- to consider the risks that connected with dynamics of changes and development;

- to take into account necessity of uncertainty of the external environment;

- to predict transition of system from one state in another by a preliminary task of parameters of external environment;

B. Adaptation programs of coal mines development has to be based on the following principles:

- system-wide principles;

- methodical principles;

- principles of the structural organization of adaptive business management;

- principles of an indicativity and measurability;

- the special (industry) principles that determined by specifics of the concrete enterprise activity.

In particular, for coal mines one of the basic principles can be considered the principle of restriction of working space updates. Realization of this principle in practice can be reached due to reuse of mine workings and, respectively, increases in stability of those mine workings which can be potentially reused, and also by increase in length of extraction pillars that provides increase in concentration of stoping operations. Further research of considered perspective also have to develop in the direction of a specification of the special principles of development of management adaptation programs of safe and sustainable development of coal mines.

In conditions of mining enterprises, technical-andtechnological environment is the most quickly changing element that gives the foundation to consider technological processes as a basis of formation of safe and sustainable development.

\section{METHODICAL FEATURES OF ADAPTATION PROGRAMS ELABORATION OF COAL MINES DEVELOPMENT}

Having considered basic elements of conceptual base of sustainable development of coal-mining enterprises and ensuring its technological safety, we can pass to statement and solution of the first analytical task: to analyze and estimate specifics of parametrical, algorithmic and resource adaptation of technological system of coal mines.

Difficulty of the solution of such task consists in various conditions of production of underground operations because of insufficiency and uncertainty of information on true parameters of the massif outside mine workings, real indicators of mining operations can significantly differ from planned (design).

Problem statement. We have the changing Technological working space of TWS representing the interacting complex of two Technological subspaces (Fig. 4):

- technological subspace TSS1 of stoping operations;

- technological subspace TSS2 of preparatory operations.

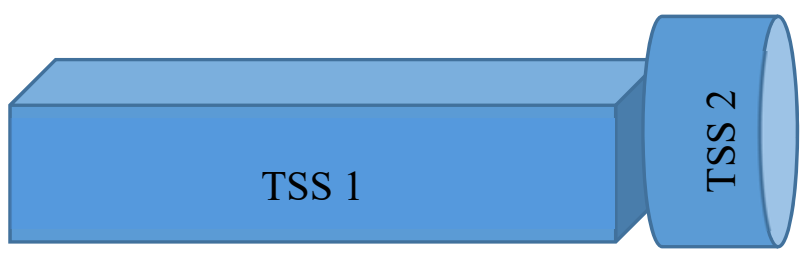

Figure 4. Technological subspaces

Changes TSS1 and TSS2 happen within plan targets. At the same time, the actual resultant values of changes are fixed as in positive (a plan overfulfillment), and in negative (failure to follow the plan) ranges of the arising sets of events. Both unforeseen combinations of conditions and mistakes in administrative decisions can be the reasons of existence of zones of non-performance of plan targets: or in aspect of establishment of the plans which aren't corresponding to the current conditions or owing to using not rational technology of mining operations conducting. The solution of a task, in broad understanding, is minimization of probability of manifestation of events in the negative range.

The choice of schemes and the sequence of updating of technological working space, and also temporary characteristics of each work (beginning, termination, duration) and determined by appointed (planned) intensities of their performance which in the maximum measure correspond to conditions of the environment of TSS1 and TSS2 is the result of solution of an objective. 
For reflection of qualitative "picture" of examined task conditions and results of work of the operating coal mines of DTEK during the period from 2012 to 2016 are considered. As the dynamic indicator of a situation, the interrelation of speed of stoping and preparatory mine workings with performance of plan targets is analyzed. The statistical set displaying this interrelation is presented on Figure 5. In general, these works of 1125 drivage and 478 stoping faces (Table 1 ) have been processed.

For finding solutions of problems of this type it is required to create a technique of a research of ways of providing economic (in aspect - technological) safety and stability of working space (TSS1 and TSS2) in conditions of its continuous change which in basic option comes down to a technique of the solution of a task of adaptive management of mining operations development and formations of the appropriate adaptation programs.

Procedures of search of the adaptive decision (or adaptive procedures) can be divided into three groups: procedures with parametrical adaptation, procedures with algorithmic (structural) adaptation and procedures with resource adaptation. The first group of procedures can be considered as a special case of the second - algorithms (structures) differ only in values of the operated parameters.

(a)

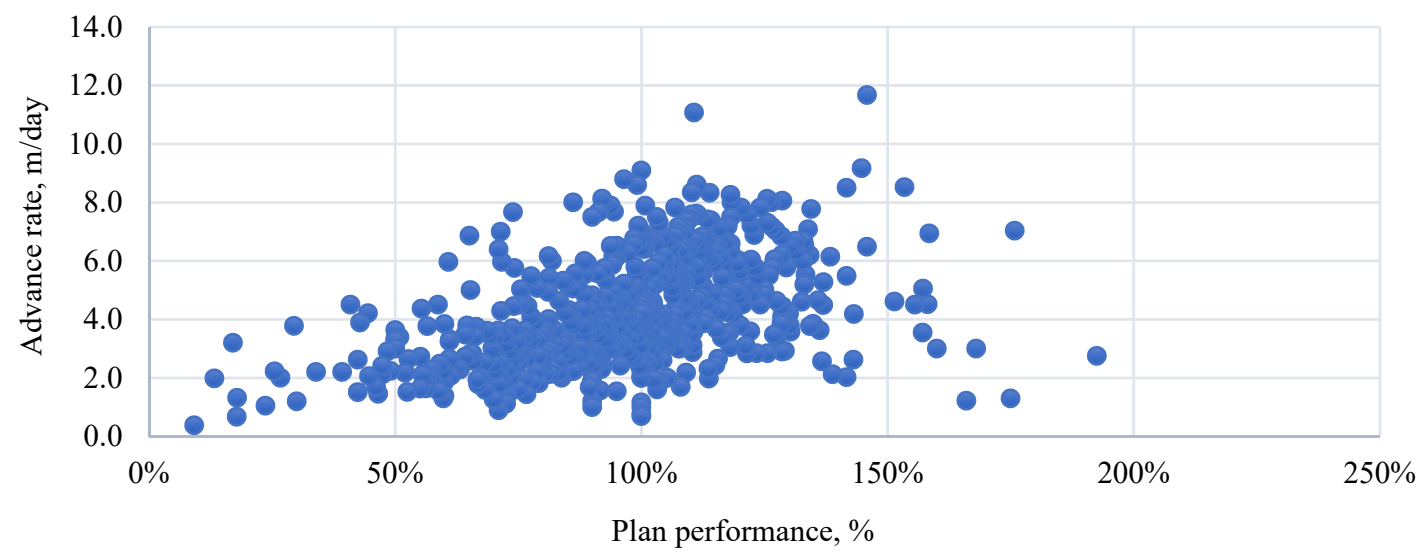

(b)

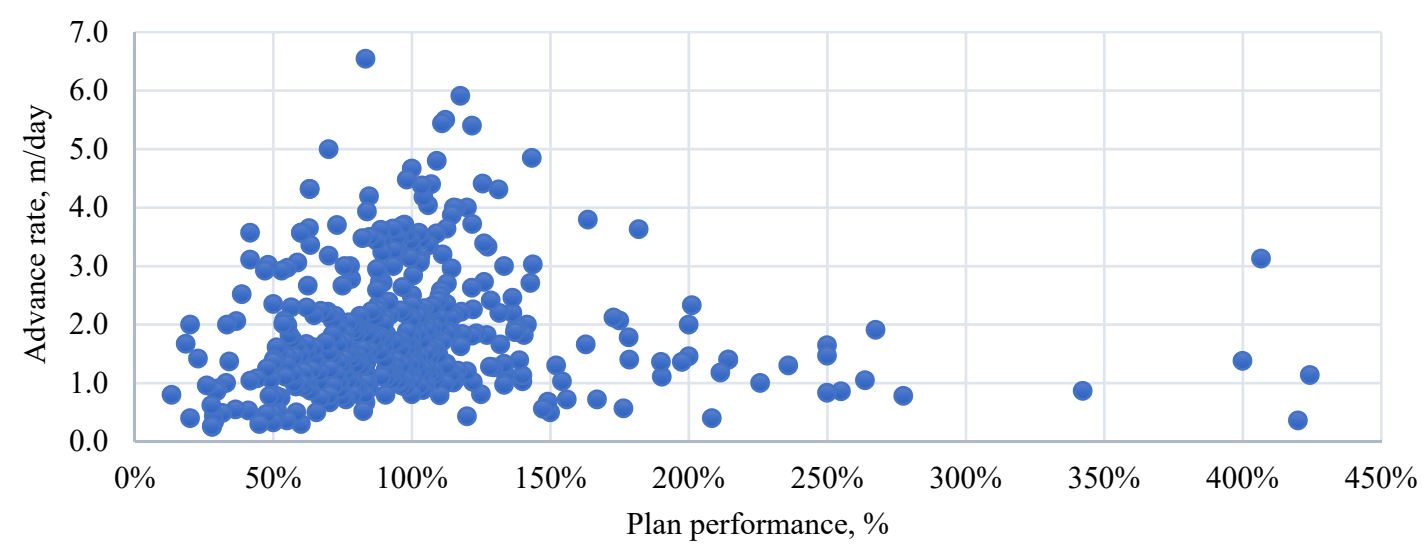

(c)

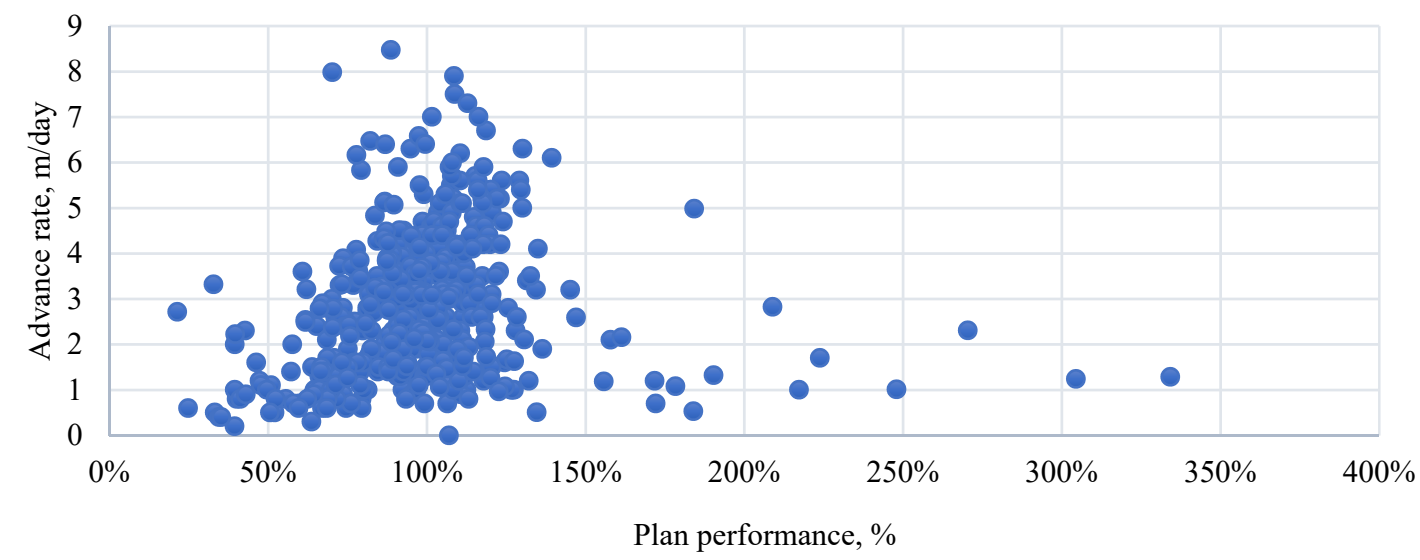

Figure 5. Statistical distribution of analyzed data: (a) plan performance at various speeds of continuous drivage; (b) plan performance at various speeds of drilling and blasting operations method; (c) plan performance at various advance rate of face 
Table 1. The volume of statistical selection on stoping and preparatory faces of DTEK coal mines

\begin{tabular}{|c|c|c|c|c|c|c|}
\hline & 2012 & 2013 & 2014 & 2015 & 2016 & Total \\
\hline $\begin{array}{l}\text { Preparatory faces } \\
\text { with continuous } \\
\text { drivage }\end{array}$ & 105 & 150 & 154 & 126 & 121 & 656 \\
\hline $\begin{array}{l}\text { Preparatory faces with } \\
\text { drilling-and-blasting } \\
\text { operations drivage }\end{array}$ & 99 & 150 & 133 & 37 & 50 & 469 \\
\hline Stoping faces & 136 & 139 & 78 & 62 & 63 & 478 \\
\hline $\begin{array}{l}\text { Total amount } \\
\text { of faces }\end{array}$ & 340 & 439 & 365 & 225 & 234 & 1603 \\
\hline
\end{tabular}

Changes of parameters and structure of system and, as a result, the operating influences for achievement of its optimum state at initial uncertainty and the changing working conditions are conducted by results of modeling. At the same time, model $F$ which consists of structure and parameters is formed:

$F=<S t, C>$,

where:

$S t$ - structure of model $F$

$C=\left(C_{-} 1, \ldots, C_{-} k\right)-$ its parameters.

Such adaptive models function in the conditions of a multicriteriality, and these criteria can be not only extreme, but also have the nature of restrictions. It induces to formulate several criteria at once and to vary their choice depending on current situation and internal requirements of the system. Thus, already the choice of criteria of adaptation is process adaptive and has to be considered during adaptation determining. Therefore, with taking into account features of difficult systems, adaptation is defined in a broad sense as process of purposeful change of parameters and structure of system which consists in determination of criteria of its functioning and performance of these criteria (Rastrigin, 1981).

The main approach to the solution of this kind of tasks is application of expert methods of an assessment and situation analysis (Kovalevska, Illiashov, Fomychov, \& Chervatuk, 2012; Bondarenko, Hardygora, Symanovych, Sotskov, \& Snihur, 2016).

In the conditions of a multicriteriality of tasks it is expedient to apply entropy approach to an assessment of situations to increase in efficiency of adoption of expert decisions. For this purpose, data of any selection can be represented in the form of Pareto-diagram, such as on Figure 6 results of defragmentation of selection on effectiveness of TSS2 changes during using of continuous methods of preparatory mine workings are displayed.

Further, we can calculate value of entropy within each fragment of the splitting received on diagram according to a formula:

$H=-\sum_{i=1}^{n} P_{i} \ln P_{i}=1$,

where:

$n$ - the number of groups into which the schedule during calculating is divided;

$P_{i}$ - value of probability of point getting into a certain group.

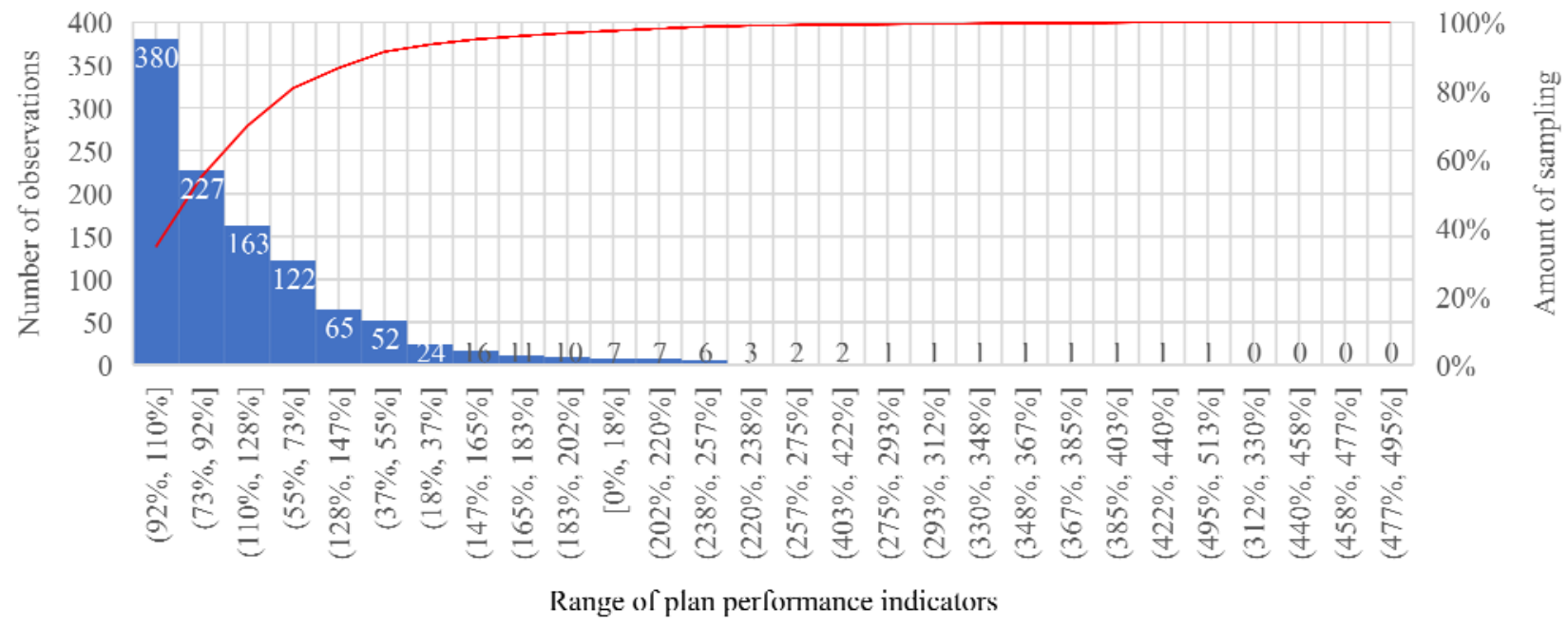

Figure 6. Total Pareto-diagram of data sampling of plan performance of preparatory mine workings during $2012-2016$

On diagram on Figure 6, significant Pareto-area includes 5 groups (ranges), the number of observations in which is equal to $81.4 \%$ of the total amount of selection (905 points of 1111 considered, data which correctness isn't confirmed weren't considered). Values of indicator of performance of plan targets in the range of values from 60 to $135 \%$ get into these groups. At the same time, if to analyze selection after a time interval (by years, from 2012 to 2016, Fig. 7), it is possible to see that significant groups in separate years can settle down in wider range therefore for the further analysis the settlement range of values of an indicator of implementation of the plan for preparatory mine workings drivage from $40 \%$ (at the minimum value of $38 \%$ in 2012 ) to $160 \%$ (at the maximum value of $152 \%$ according to 2012) is determined.

Value of entropy on a total indicator of plan targets performance on preparatory mine workings drivage during 2012 - 2016 are defined on the basis of the calculations that presented in Tables $2-4$. From Figure 8 it is follows that the probability of plan targets performance on preparatory mine workings drivage on DTEK mines during $2012-2016$ was equal to $50 \%$. 
(a)

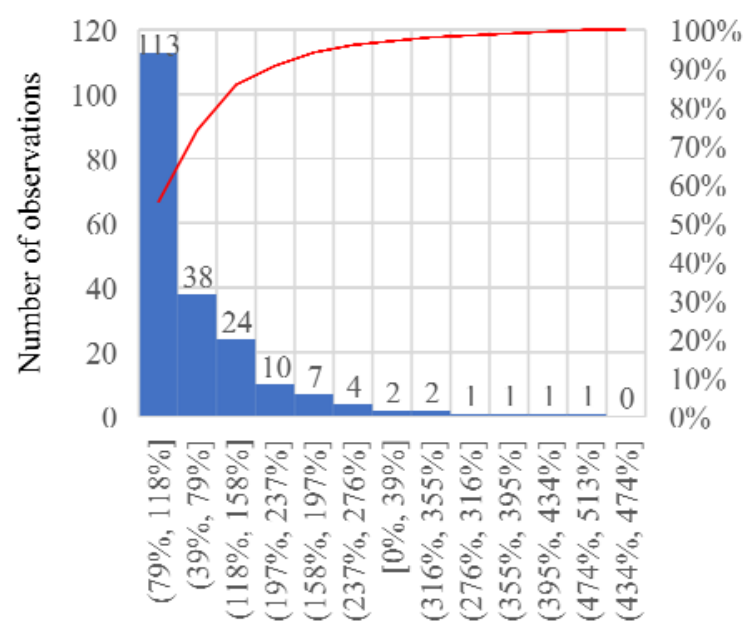

Range of plan performance indicators

(c)

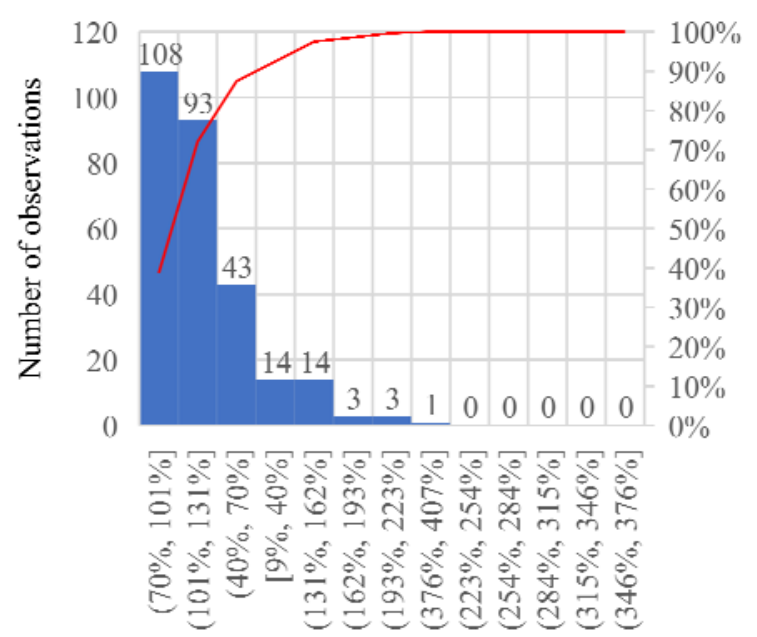

Range of plan performance indicators (b)

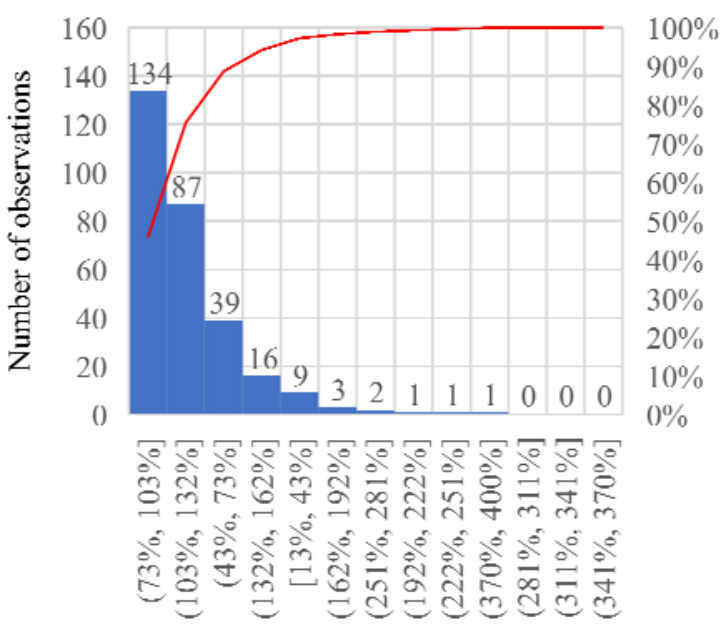

Rangc of plan performance indicators

(d)

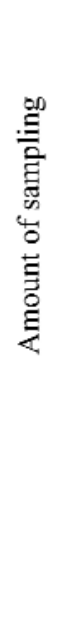

(e)

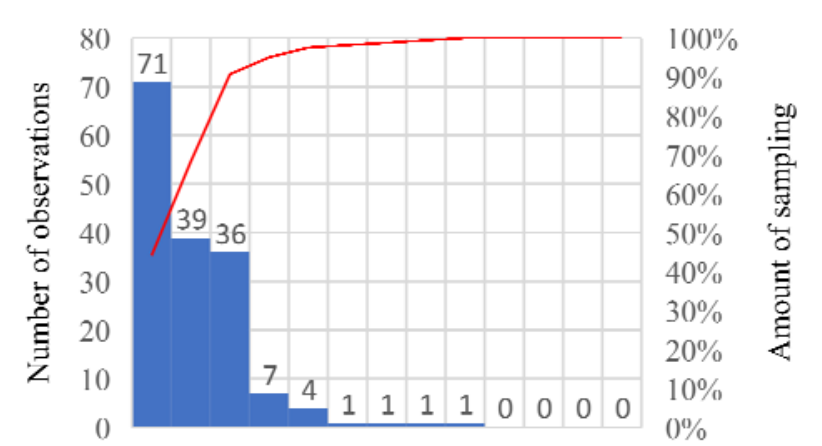

సัं

0.000 .

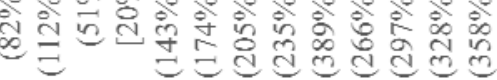

Rangc of plan performance indicators 
Table 2. Calculation of entropy for a total indicator of plan targets performance for preparatory mine workings drivage during $2012-2016$

\begin{tabular}{|c|c|c|c|c|c|c|c|c|}
\hline \multirow[b]{2}{*}{ Index } & \multicolumn{8}{|c|}{ Defragmentation of sampling on value groups, $\%$} \\
\hline & $<40.00$ & $\begin{array}{l}40.00- \\
59.99 \\
\end{array}$ & $\begin{array}{l}60.00- \\
79.99 \\
\end{array}$ & $\begin{array}{c}80.00- \\
99.99 \\
\end{array}$ & $\begin{array}{c}100.00- \\
119.99 \\
\end{array}$ & $\begin{array}{c}120.00- \\
139.99 \\
\end{array}$ & $\begin{array}{c}140.00- \\
160.00 \\
\end{array}$ & $>160.00$ \\
\hline $\begin{array}{l}\text { The number of obser- } \\
\text { vations in group }(n)\end{array}$ & 33 & 78 & 163 & 280 & 368 & 103 & 28 & 52 \\
\hline $\begin{array}{l}\text { Value of probability } \\
\text { for each group }\left(P_{i}\right)\end{array}$ & 0.03 & 0.07 & 0.15 & 0.25 & 0.33 & 0.09 & 0.03 & 0.05 \\
\hline $\begin{array}{l}\text { Logarithm of proba- } \\
\text { bility of group }\left(\ln P_{i}\right)\end{array}$ & -3.51 & -2.66 & -1.90 & -1.39 & -1.11 & -2.41 & -3.51 & -3.00 \\
\hline $\begin{array}{l}\text { Value of entropy } \\
\text { on groups }\left(H_{i}\right)\end{array}$ & -0.11 & -0.19 & -0.29 & -0.35 & -0.37 & -0.22 & -0.11 & -0.15 \\
\hline $\begin{array}{l}\text { Total value } \\
\text { of entropy }(H)\end{array}$ & & & & 0.94 & & & & 1.79 \\
\hline
\end{tabular}

Table 3. Calculation of entropy on single (for 1 year) indicators of plan targets performance on preparatory mine workings drivage during $2012-2016$

\begin{tabular}{|c|c|c|c|c|c|c|c|c|c|}
\hline \multirow[b]{2}{*}{ Index } & \multirow[b]{2}{*}{ Year } & \multicolumn{8}{|c|}{ Defragmentation of sampling on value groups } \\
\hline & & $<40.00$ & $\begin{array}{c}40.00- \\
59.99\end{array}$ & $\begin{array}{c}60.00- \\
79.99\end{array}$ & $\begin{array}{c}80.00- \\
99.99\end{array}$ & $\begin{array}{c}100.00- \\
119.99\end{array}$ & $\begin{array}{c}120.00- \\
139.99\end{array}$ & $\begin{array}{c}140.00- \\
160.00\end{array}$ & $>160.00$ \\
\hline \multirow{5}{*}{$\begin{array}{l}\text { The number } \\
\text { of observations } \\
\text { in group }(n)\end{array}$} & 2012 & 2 & 10 & 28 & 45 & 68 & 17 & 7 & 27 \\
\hline & 2013 & 8 & 17 & 46 & 84 & 98 & 22 & 10 & 8 \\
\hline & 2014 & 14 & 27 & 43 & 67 & 93 & 23 & 5 & 7 \\
\hline & 2015 & 4 & 13 & 25 & 35 & 51 & 25 & 2 & 6 \\
\hline & 2016 & 5 & 11 & 21 & 49 & 58 & 16 & 4 & 4 \\
\hline \multirow{5}{*}{$\begin{array}{l}\text { Value of probability } \\
\text { for each group }\left(P_{i}\right)\end{array}$} & 2012 & 0.01 & 0.05 & 0.14 & 0.22 & 0.34 & 0.08 & 0.03 & 0.13 \\
\hline & 2013 & 0.03 & 0.06 & 0.16 & 0.29 & 0.33 & 0.07 & 0.03 & 0.03 \\
\hline & 2014 & 0.05 & 0.10 & 0.15 & 0.24 & 0.33 & 0.08 & 0.02 & 0.03 \\
\hline & 2015 & 0.02 & 0.08 & 0.16 & 0.22 & 0.32 & 0.16 & 0.01 & 0.03 \\
\hline & 2016 & 0.03 & 0.07 & 0.13 & 0.29 & 0.35 & 0.09 & 0.02 & 0.02 \\
\hline \multirow{5}{*}{$\begin{array}{l}\text { Logarithm of } \\
\text { probability } \\
\text { of group }\left(\ln P_{i}\right)\end{array}$} & 2012 & -4.61 & -3.00 & -1.97 & -1.51 & -1.08 & -2.53 & -3.51 & -2.04 \\
\hline & 2013 & -3.51 & -2.81 & -1.83 & -1.24 & -1.11 & -2.66 & -3.51 & -3.51 \\
\hline & 2014 & -3.00 & -2.30 & -1.90 & -1.43 & -1.11 & -2.53 & -3.91 & -3.51 \\
\hline & 2015 & -3.91 & -2.53 & -1.83 & -1.51 & -1.14 & -1.83 & -4.61 & -3.51 \\
\hline & 2016 & -3.51 & -2.66 & -2.04 & -1.24 & -1.05 & -2.41 & -3.91 & -3.91 \\
\hline \multirow{5}{*}{$\begin{array}{l}\text { Value of entropy } \\
\text { on groups }\left(H_{i}\right)\end{array}$} & 2012 & -0.05 & -0.15 & -0.28 & -0.33 & -0.37 & -0.20 & -0.11 & -0.26 \\
\hline & 2013 & -0.11 & -0.17 & -0.29 & -0.36 & -0.37 & -0.17 & -0.11 & -0.11 \\
\hline & 2014 & -0.15 & -0.23 & -0.29 & -0.34 & -0.37 & -0.20 & -0.08 & -0.11 \\
\hline & 2015 & -0.08 & -0.20 & -0.29 & -0.33 & -0.36 & -0.29 & -0.05 & -0.11 \\
\hline & 2016 & -0.11 & -0.19 & -0.27 & -0.36 & -0.37 & -0.22 & -0.08 & -0.08 \\
\hline \multirow{5}{*}{$\begin{array}{l}\text { Total value } \\
\text { of entropy }(H)\end{array}$} & 2012 & & & & 0.81 & & & & 1.75 \\
\hline & 2013 & & & & 0.93 & & & & 1.69 \\
\hline & 2014 & & & & 1.01 & & & & 1.77 \\
\hline & 2015 & & & & 0.90 & & & & 1.71 \\
\hline & 2016 & & & & 0.93 & & & & 1.68 \\
\hline
\end{tabular}

Table 4. Sampling of calculated values of entropy on a drivage

\begin{tabular}{|c|c|c|c|c|c|c|c|c|}
\hline \multirow{3}{*}{ Period } & 1 & 2 & 3 & 4 & 5 & 6 & 7 & 8 \\
\hline & \multirow{2}{*}{$<40.00$} & $40.00-$ & $60.00-$ & $80.00-$ & $100.00-$ & $120.00-$ & $140.00-$ & \multirow{2}{*}{$>160.00$} \\
\hline & & 59.99 & 79.99 & 99.99 & 119.99 & 139.99 & 160.00 & \\
\hline 2012 & -0.05 & -0.15 & -0.28 & -0.33 & -0.37 & -0.20 & -0.11 & -0.26 \\
\hline 2013 & -0.11 & -0.17 & -0.29 & -0.36 & -0.37 & -0.17 & -0.11 & -0.11 \\
\hline 2014 & -0.15 & -0.23 & -0.29 & -0.34 & -0.37 & -0.20 & -0.08 & -0.11 \\
\hline 2015 & -0.08 & -0.20 & -0.29 & -0.33 & -0.36 & -0.29 & -0.05 & -0.11 \\
\hline 2016 & -0.11 & -0.19 & -0.27 & -0.36 & -0.37 & -0.22 & -0.08 & -0.08 \\
\hline Total on drivage & -0.11 & -0.19 & -0.29 & -0.35 & -0.37 & -0.22 & -0.11 & -0.15 \\
\hline
\end{tabular}




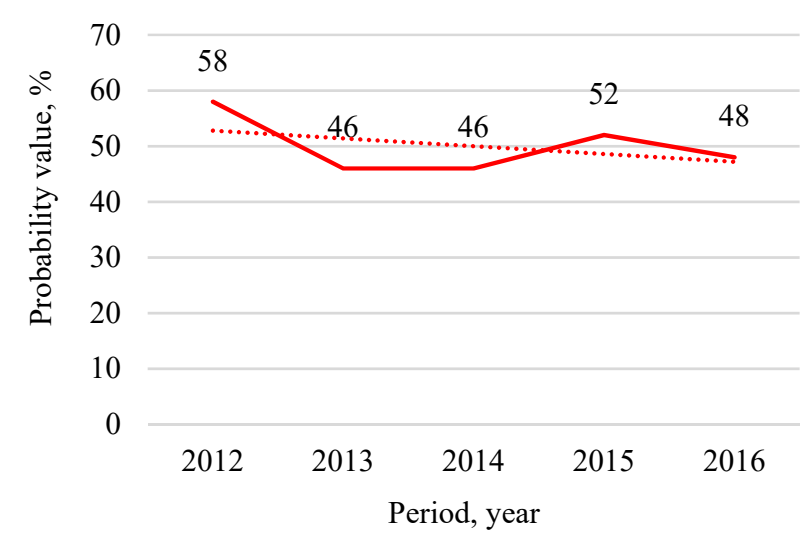

Figure 8. The schedule of probability of plan targets performance on preparatory mine workings drivage during $2012-2016$

Range from 0 to $40 \%$ are characterized by the greatest uncertainty that confirms existence of weakly-predicted situations that connected with sharp deterioration in mining-and-geological conditions as follows from the schedule that submitted on Figure 9.

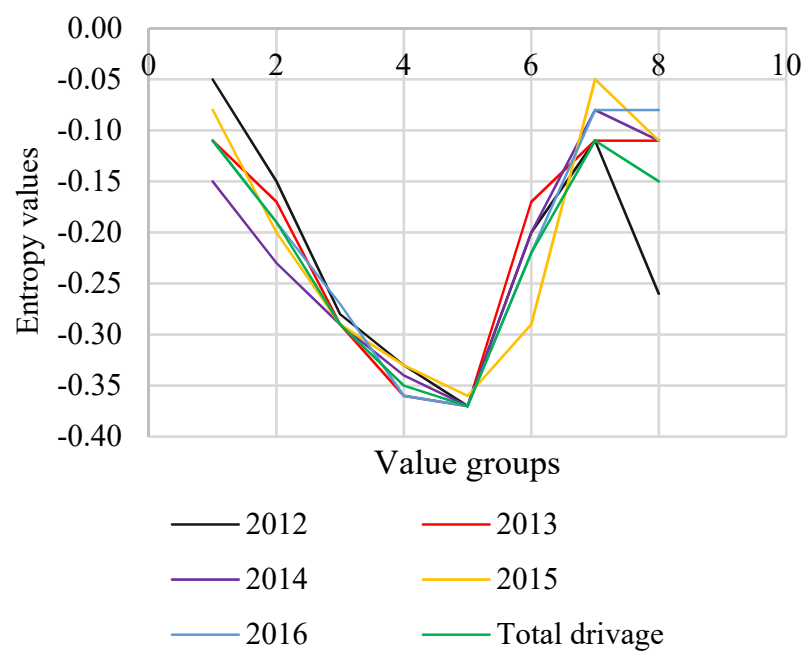

Figure 9. The schedule of entropy values (uncertainty level) of plan targets on preparatory mine workings drivage

The probability of approach of events of such plan is equal to $6-15 \%$. And here almost equal values of entropy (uncertainty level) in the range from 40 to $100 \%$ of plan performance for a drivage reflects an incorrect assessment of a condition of technological space at the level of planning. And, respectively, the probability of failure to follow the plan as a result of such actions of managers is equal to $36-45 \%$.

For identification of the concrete reasons and definition of preparatory operations necessary for transformations of an algorithm of maintaining, it is necessary to conduct analysis of influence of separate mining-and-geological and production factors.

Similar procedures of the analysis are performed also for an assessment of a technological subspace of stoping operations.

\section{CONCLUSIONS}

As a result of the executed analysis, it is established that concepts of "sustainable development" and "economic security of the enterprise" are crossed in a set of definitions and factors which form and reflect their essence. Being guided by provisions of dialectic logic in a tandem these phenomena, it is possible to consider at the same time as process and as the mechanism of its providing.

It, in turn, means that planning of stoping and preparatory operations demands optimization of analytical procedures and an assessment of structure and condition of technological space of the enterprise. The required algorithm of changes of technological working space has to:

- provide performance of planned targets on volumes, types and quality of mine workings;

- conduct strict spatial and temporary coordination of the planned works;

- provide maintenance for technological sequence of changes of TSS1 and TSS2, not to allow its critical deviations;

- provide continuous updating of TSS2 with taking into account regulated breaks in changes of TSS2;

- provide planned loadings of mining sections in subcritical limits.

Adaptation activity at the enterprise always needs either in current, or perspective resources. Practical ability to conduct resource support of process of adaptation also reflects, in fact, a possibility of ensuring economic security of the enterprise. And as, in this case, the technological subsystem of the coal mine is considered, so we will talk about resource adaptation in aspect of process of technological safety ensuring of the enterprise.

\section{ACKNOWLEDGEMENTS}

Authors express gratitude for the help and consultations during work performing for director of management of coal mining of LLC "DTEK Energy" Mykhailo Barabash.

\section{REFERENCES}

Amoosha, O., Starichenko, L., \& Cherevatskyi, D. (2013). State, Main Problems and Prospects of the Ukraine Coal Industry. NAS of Ukraine, The institute of the Economy of Industry, 25-36.

Bondarenko, V., Hardygora, M., Symanovych, H., Sotskov, V., \& Snihur, V. (2016). Numerical Methods of Geomechanics Tasks Solution During Coal Deposits' Development. Mining of Mineral Deposits, 10(3), 1-12. https://doi.org/10.15407/mining10.03.001

Chernyak, L. (2004). Adaptiruemost' i adaptivnost'. Otkrytye sistemy, SUDB, pp. 9. Retrieved from https://www.osp.ru/ os/2004/09/184560/

Dhookie, V.I. (2016). Impact of New Technologies in Hard Rock Underground Mining Taking into Account Operational Efficiencies and Production Rates. Mining of Mineral Deposits, 10(4), 56-60. https://doi.org/10.15407/mining10.04.056

Derun, I. (2016). Risk Identification in the Company's Accounting System. Economic Annals-XXI, 159(5-6), 97-100. https://doi.org/10.21003/ea.v159-21 
Kharlamova, G., Nate, S., \& Chernyak, O. (2016). Renewable Energy and Security for Ukraine: Challenge or Smart Way? Journal of International Studies, 9(1), 88-115.

Khetagurova, T.G., \& Khetagurova, I.Yu. (2013). Protsessy adaptatsii gornykh predpriyatiy $\mathrm{k}$ izmeneniyam okruzhayushchey sredy. Ustoychivoe Razvitie Rornykh Territoriy, 2(16), 97-99.

Kovalevska, I., Illiashov, M., Fomychov, V., \& Chervatuk, V. (2012). The Formation of the Finite-Element Model of the System "Undermined Massif - Support of Stope". Geomechanical Processes During Underground Mining 2012, 73-79.

https://doi.org/10.1201/b13157-13
Rastrigin, L.A. (1981). Adaptatsiya slozhnykh sistem. Riga: Zinatne. Salli, S., Mamaykin, O., \& Smolanov, S. (2013). Inner Potential of Technological Networks of Coal Mines. Mining of Mineral Deposits, 243-246.

https://doi.org/10.1201/b16354-46

Slobodchikova, O.A. (2016). Mechanism of Ensuring the Strategic Sustainability of the Metallurgical Enterprise in Terms of Restructuring. Economic Annals-XXI, (7-8), 44-46.

Trifonova, O.V. (2015). Upravlinnia stiikym funktsionuvanniam vuhledobuvnykh pidpryiemstv: teoriia ta praktyka. Dnipropetrovsk: Natsionalnyi hirnychyi universytet.

Vorotnikov, V. (2014). Ukraine Coal Industry Captured by the Ongoing Armed Conflict. Coal Age, 119(10), 38-39.

\section{ABSTRACT (IN UKRAINIAN)}

Мета. Обгрунтування концептуальної бази пошуку шляхів запобігання загрозам сталого розвитку вугільних підприємств при наявності різноспрямованих векторів економічного тиску зовнішнього середовища.

Методика. Для вирішення поставлених у роботі завдань використані методи структурно-порівняльного аналізу - для оцінки використання основних дефініцій дослідження, їх сутності та зв'язку з іншими категоріями, які визначають ефективність розвитку вугільного підприємства; групування й класифікації - для систематизації видів економічної безпеки і стійкості підприємства, а також факторів, які їх обумовлюють.

Результати. Проведено аналіз основних визначень, що відображають сутність таких наукових феноменів, як “сталий розвиток” і “економічна безпека" підприємства. Обгрунтована актуальність та доцільність проведення наукових досліджень з формування методичної бази й інструментарію оцінки технологічної складової безпеки сталого розвитку вугільних підприємств.

Наукова новизна. Дослідження можливостей створення комплексних програм адаптивного управління гірничим підприємством, що включають ретроспективну і перспективну оцінки траєкторії його розвитку.

Практична значимість. Впровадження адаптаційної діяльності на вугільних підприємствах в аспекті процесу забезпечення технологічної безпеки.

Ключові слова: вугільне підприємство, технологічна безпека, економічна стійкість, стійке функціонування

\section{ABSTRACT (IN RUSSIAN)}

Цель. Обоснование концептуальной базы поиска путей предотвращения угроз устойчивому развитию угольных предприятий при наличии разнонаправленных векторов экономического давления внешней среды.

Методика. Для решения поставленных в работе задач использованы методы структурно-сравнительного анализа - для оценки использования основных дефиниций исследования, их сущности и связи с другими категориями, которые определяют эффективность развития угольного предприятия; группировки и классификации - для систематизации видов экономической безопасности и устойчивости предприятия, а также факторов, которые их обусловливают.

Результаты. Проведен анализ основных определений, отражающих сущность таких научных феноменов, как "устойчивое развитие" и “экономическая безопасность” предприятия. Обоснована актуальность и целесообразность проведения научных исследований по формированию методической базы и инструментария оценки технологической составляющей безопасности устойчивого развития угольных предприятий.

Научная новизна. Исследование возможностей создания комплексных программ адаптивного управления горным предприятием, включающих ретроспективную и перспективную оценку траектории его развития.

Практическая значимость. Внедрение адаптационной деятельности на угольных предприятиях в аспекте процесса обеспечения технологической безопасности.

Ключевые слова: угольное предприятие, технологическая безопасность, экономическая устойчивость, устойчивое функиионирование

\section{ARTICLE INFO}

Received: 26 December 2016

Accepted: 14 April 2017

Available online: 30 June 2017 


\section{ABOUT AUTHORS}

Volodymyr Bondarenko, Doctor of Technical Sciences, Head of the Underground Mining Department, National Mining University, 19 Yavornytskoho Ave., 4/56, 49005, Dnipro, Ukraine. E-mail: v domna@yahoo.com

Volodymyr Cherniak, Candidate of Technical Sciences, Associate Professor of the Production Sphere Management Department, National Mining University, 19 Yavornytskoho Ave., 4/99, 49005, Dnipro, Ukraine. E-mail: vi_chernyak@ukr.net

Frederick Cawood, Doctor of Philosophy, Director of the Wits Mining Research Institute, University of the Witwatersrand, 1 Jan Smuts Ave., 2000, Johannesburg, South Africa. E-mail: Frederick.Cawood@,wits.ac.za

Volodymyr Chervatiuk, Candidate of Technical Sciences, Deputy Director for Production of the LLC "DTEK Energy", 57 Lva Tolstoho St, 01032, Kyiv, Ukraine. E-mail: ChervatyukVG@dtek.com 